\title{
A Godless Constitution? Faith, Politics and Speech in the Bill of Rights of the United States
}

\author{
Herman T. Salton ${ }^{1}$ \\ ${ }^{1}$ Department of International Politics, University of Wales, Aberystwyth, UK \\ Correspondence: Dr Herman T. Salton, Department of International Politics, Room 3.25, University of Wales, \\ Penglais Campus, Aberystwyth SY23 3FE, UK. Tel: 44-197-062-1610. E-mail: hes3@aber.ac.uk
}

Received: August 27, 2012 Accepted: September 24, 2012 Online Published: October 26, 2012

doi:10.5539/ilr.v1n1p1 URL: http://dx.doi.org/ilr.v1n1p1

\begin{abstract}
This article takes a fresh look at the place of religion in the US Constitution. By reviewing the most important literature on the First Amendment and by considering the key judicial rulings on the matter, this piece argues that US constitutional law adopts an exceptionally careful approach when it comes to the place of religion in America's public sphere. This approach is both sympathetic towards private belief, yet uncompromising about the importance of Church-State separation. I conclude that the distinction of the US legal system lies within its very capacity for achieving this balance.
\end{abstract}

Keywords: first amendment, establishment clause, religion, separation, church and state, United States

\section{Introduction}

The complexity of America's relationship with religion is nowhere more apparent than in its legal system. The Founding Fathers agreed on the importance of religion for the American Nation, but were also aware of the dangers that a connection between secular and spiritual authorities posed to the existence of their highly pluralistic polity. The tough question they faced, therefore, was how to reconcile a Christian but multi-denominational country with religious freedom for all. The answer they gave was as genial as it was ambiguous: precisely because religion was so important and so divisive, it was not the business of the federal government to deal with it. It was, however, the business of enlightened constitutional framers to guarantee both the separation of the civil from the sacred, as well as the protection of religious freedom in general. The carefully drafted compromise was reached in 1791 and resulted in the seemingly uncomplicated formula of the US First Amendment: "Congress shall make no law respecting an establishment of religion or prohibiting the free exercise thereof, or abridging the freedom of speech, or of the press, or the right of people peaceably to assemble and to petition the Government for redress of grievances."

The First Amendment is a uniquely American product, the direct result of the country's historical legacy. It is an amalgam of the five key freedoms to be found in any democratic polity-religion, expression, press, assembly and petition - and, as such, it is the pivot around which the entire US constellation of rights turns. However, by no means is the passage easy to comprehend, precisely because it fulfills so many functions at once, and rarely has the interpretative history of a constitutional provision raised more problems. "People who disagree about nearly everything else in the law agree that the Establishment Clause doctrine is seriously, perhaps distinctively, defective", one author observed (Gedicks, 1995: 1). Yet it is the construction of the First Amendment in its entirety that is problematic, and given its broad wording and crucial role in US law, this is hardly surprising. From the very beginning, the courts were faced with the daunting task of clarifying in precise terms what even the Founding Fathers could only summarily sketch: namely, a definition of freedom in America. That the Framers managed to build such a construction in forty-five words is thus not only a testimony to their prescient genius but also to the complexity of their chosen formula, a complexity that the judiciary subsequently reflected. This contribution is dedicated to such judicial intricacy.

\section{The 'Marketplace of Ideas' and the Importance of Freedom of Expression in US Law}

In the eighteenth century an unprecedented number of events-increased population, migration, the Great Awakening, unrest among the black population and the Enlightenment - transformed America from a place that punished dissent into a place where heterodoxy and criticism were the norm, a 'marketplace of ideas', as it has 
been called (Note 1). There is, historically speaking, much speculation on whether this marketplace was the cause or the consequence of the religious fervour that inflamed the US in those years. Whatever the historical truth, however, the First Amendment treats religion as a form of expression (albeit a particularly important one). Therefore, before turning to the religion clauses of the First Amendment, we need to consider the degree of protection given by US law to free expression in general, as the former considerably benefits from, and significantly expands upon, the guarantees given to the latter.

\subsection{The 'Marketplace of Ideas' and the US Supreme Court}

The 'marketplace of ideas' theory was first spelled out by John Stuart Mill in 1859 in his Liberty of Thought and Discussion, an essay where the author argued that an erroneous idea is as valuable as a truthful one because without the former, the latter would lose part of its strength. Banning wrong opinions, Mill thought, is damaging because it deprives humanity of "the clearer perception and livelier impression of truth, produced by its collision with error" (Mill, 1999: 121). Although this idea of free expression as the best antidote against error was at the time rejected by the British, it was enthusiastically embraced on the other side of the Atlantic and became an ingrained part of the country's psyche, particularly from the mid-twentieth century onwards (Lambert, 2002: 203). It is the theoretical underpinning upon which the US judiciary wrote a good portion of First Amendment jurisprudence. It helps explain the central role given to free expression by US law, as well as the contention that in America, everything in the end becomes a First Amendment question. "The ultimate good desired is better reached by free trade in ideas", Justice Holmes wrote in Abrams v United States (1919: 250 US 616), the first judicial endorsement of the marketplace model. "The best test of truth is the power of the thought to get accepted in the competition of the market, because truth is the only ground upon which people's wishes safely can be carried out" (250 US 630).

The Supreme Court has explicitly adopted this model but has not always ruled consistently with it, and it is significant that Justice Holmes wrote in dissent. Yet the marketplace model conveys one central principle underlying First Amendment jurisprudence, namely, the extraordinary protection accorded to free expression by US law vis-à-vis the minimal governmental interference allowed on the matter. Since the marketplace of ideas is only one step away from the marketplace of religions, it is important to analyze briefly, in chronological order, the most significant passages of the Supreme Court's conceptual journey in establishing such a model and in giving it the protection of the law.

\subsubsection{Flag Salute, Libel Actions and Student Symbolism}

An early application of the 'marketplace of ideas' was West Virginia Board of Education v Barnette (1943: 319 US 624), a case concerning compulsory flag salute and recitation of the pledge of allegiance at school. Here the Supreme Court, by a 6-3 majority, held unconstitutional a measure that obliged public school students, without exceptions or opt-out provisions, to salute the flag and recite the pledge of allegiance daily. The case is significant because it recognized that the purpose of the First Amendment is to ensure that individuals have a private sphere of freedom of thought and belief that even the government or its agencies (like schools) cannot invade. "If there is any fixed star in our constitutional constellation", Justice Jackson famously wrote in a key passage, "it is that no official, high or petty, can prescribe what shall be orthodox in politics, nationalism, religion or other matters of opinion or force citizens to confess by word or act their faith therein" (319 US 642). When Justice Frankfurter, in dissent, objected that the flag salute and pledge recitation could legitimately be imposed by the government since they are not religious acts but merely practices "promoting good citizenship and national allegiance" (319 US 654), the majority answered that this was irrelevant because government officials cannot compel individuals to espouse beliefs at odds with their conscience, no matter whether they are religious or not. "Authority here is to be controlled by public opinion", the Court concluded, "not public opinion by authority" (319 US 641).

The most interesting period for the marketplace model in US law is undoubtedly that of the 1960s and 1970s, a time when national tumult and social unrest percolated to the Supreme Court. In a series of decisions, the justices emphasized the central—indeed, sacred - importance given to First Amendment freedoms, and the best known of these cases is New York Times v Sullivan (1964: 376 US 254). A newspaper had published an advertisement soliciting funds to cover the legal expenses of jailed students protesting against racial segregation, but contained a number of factual mistakes, such as allegations of police attacks on demonstrators. A police commissioner sued for libel and was awarded $\$ 500,000$ but the Supreme Court reversed the ruling, upholding the newspaper's right to criticize government officials. Writing for the Court, Justice Brennan justified the decision by reference to "the background of a profound national commitment to the principle that debate on public issues should be uninhibited, robust and wide-open, and that it may well include vehement, caustic and sometimes unpleasantly 
sharp attacks on government and public officials" (376 US 270). Instead of censorship, the best way forward for society was rebuttal of factual inaccuracies through counter-speech (376 US 297).

A few years later, the Supreme Court again had the opportunity to balance free expression and state interests in a case particularly important for the heated political situation of the time. In Tinker v Des Moines School District (1969: 393 US 503) the question was whether a public school regulation prohibiting students from wearing armbands against the Vietnam War was constitutional. By a 7-2 majority, the Court decided that it was not. "It can hardly be argued that either students or teachers shed their constitutional rights to freedom of speech or expression at the schoolhouse gates" (393 US 506), Justice Fortas wrote for the majority. "In our system, state-operated schools may not be enclaves for totalitarianism and students may not be regarded as close-circuit recipients of only that which the State chooses to communicate" (393 US 511). School officials, the Court concluded, cannot censor student speech simply because of an "undifferentiated fear or apprehension" (393 US 508), but "must reasonably forecast that the student speech will cause a substantial disruption or invade the rights of others" (393 US 514).

Justice Hugo Black disagreed with this stance and in a forceful dissent accused the Court of ushering in "a new revolutionary era of permissiveness in this country fostered by the judiciary" (393 US 518). Yet the case is significant precisely because of the majority's answer to Justice Black's objection: "Any departure from absolute regimentation may cause trouble", the Tinker court wrote. "Any variation from the majority's opinion may inspire fear. Any word spoken, in class, in the lunchroom, or on the campus, that deviates from the view of another person may start an argument or cause a disturbance. But our Constitution says that we must take this risk... and our history says that it is this sort of hazardous freedom, this kind of openness, that is the basis of our national strength..." (393 US 508-9). Importantly, this strength was precisely the 'marketplace of ideas' embodied by the First Amendment (Note 2).

\subsubsection{Hate Speech, Vulgar Speech and School Censorship}

The attachment to freedom of expression in the US is perhaps most noteworthy in relation to anti-discrimination laws, and Brandenburg $v$ Ohio (1969: 395 US 444) is one of the most contentious decisions on the matter. The case involved a video showing Ku-Klux-Klan supporters, some hooded and carrying firearms, gathering around a large burning cross and making racist remarks such as "This is what we are going to do to the niggers", "A dirty nigger", "Send the Jews back to Israel", "Bury the niggers" and "Save America" (395 US 445-6). The appellant was a KKK leader and was shown in the video making a speech in which he said: "We're not a revengent organization, but if our President, our Congress, our Supreme Court, continues to suppress the white, Caucasian race, it's possible that there might have to be some revengence taken" (395 US 446). Mr Brandenburg was convicted under an Ohio statute that prohibited advocating criminal syndicalism, but the Supreme Court found that his speech was mere encouragement rather than actual incitement to violence and overturned the conviction. The First Amendment, the Court said, protected Mr Brandenburg's speech because "the constitutional guarantees of free speech and free press do not permit a State to forbid or proscribe advocacy of the use of force or of law violation except where such advocacy is directed to inciting or producing imminent lawless action and is likely to incite or produce such action" (395 US 447). The concurring opinion of Justice Black left no doubt as to the importance of free speech in US law: "Government has no power to invade that sanctuary of belief and conscience" (395 US 457), even if that meant advocating racial superiority.

Justice Black's "sanctuary" of free expression was again under attack two years later, and once more America's highest Court respectfully declined to invade it out of devotion to the 'marketplace of ideas'. In Cohen $v$ California (1971: 403 US 15) a man was convicted for expressing his views against the compulsory Vietnam conscription by painting the words "Fuck the Draft" on his jacket and wearing it in a courthouse. The Supreme Court nonetheless reversed the decision because it violated the man's freedom of expression: "We cannot indulge the facile assumption that one can forbid particular words without also running a substantial risk of suppressing ideas in the process", Justice Harlan wrote for the majority. "Indeed, governments may soon seize upon the censorship of particular words as a convenient guise for banning the expression of unpopular views" (403 US 29). The justices recognized the "distasteful" (403 US 21) character of Mr Cohen's expression but held that "surely the state has no right to cleanse public debate to the point where it is grammatically palatable to the most squeamish among us" (403 US 25). The best remedy, the Court convened, was, and remained, the free marketplace of ideas.

Several other cases in the 1980s and 1990s reaffirmed this determined belief in free expression, Board of Education v Pico (1982: 457 US 853) being the key example. The lawsuit involved a school decision to withdraw some books, including civil rights pieces on racial discrimination, from the library because they were 
considered inappropriate for young people. The Supreme Court, however, decided that school officials had violated the First Amendment because academic forums should encourage the free exchange of ideas, not limit it "Local school boards may not remove books from school library shelves simply because they dislike the ideas contained in those books and seek by their removal to 'prescribe what is orthodox in politics, nationalism, religion or other matters of public opinion"” (457 US 872), the Court ruled. The free flow of information had to prevail and was all the more important in a case involving a school, which the Court defined as "the principal locus of academic freedom" (457 US 868).

\subsubsection{American Flag, Racial Speech and Public Parade}

This liberal stance was reaffirmed a few years later in Texas $v$ Johnson (1989: 491 US 397), one of the most controversial examples of the 'free marketplace of ideas' model. During a political demonstration, Mr Johnson publicly burned the nation's flag and chanted: "America, the red, white and blue, we spit on you" (491 US 399). He was convicted under a Texas law that prohibited the "desecration of a venerated object" (Texas Penal Code, 1989: 42.09 (a) (3)) but the Supreme Court ruled in his favour and struck down the Texas statute on the grounds that it illegitimately restricted his freedom of expression. "If there is a bedrock principle underlying the First Amendment", Justice Brennan wrote for the majority, "it is that the government may not prohibit the expression of an idea simply because society finds the idea itself offensive or disagreeable" (491 US 414). Chief Justice Rehnquist, together with two other justices, strongly dissented on the grounds that the national flag had a unique place in America "that justifies a governmental prohibition against flag burning..." (491 US 422). Nevertheless, the majority was undeterred and noted that its ruling simply reflected the importance given to dissent by the First Amendment (Note 3). Johnson provoked a political firestorm and in 1990, Congress passed a federal law against flag-burning (Flag Protection Act, 1990: 700). The Supreme Court once again struck down the legislation on the basis of the free market of ideas in United States v. Eichman (1990: 496 US 310). As Justice Kennedy noted in Johnson, "it is poignant but fundamental that the flag protects those who hold it in contempt" (491 US 414). Far from being a weakness, the freedom to express controversial opinions is, according to the Supreme Court, America's greatest asset.

More than twenty years after Brandenburg, the Supreme justices ruled RAV v City of St.Paul (1992: 505 US 377), another case that, as counsel for petitioner argued at the hearing, "once again will demonstrate whether or not there is room for the freedom for the thought that we hate and for the eternal vigilance necessary for the opinions that we loathe" (Irons, 1997: 201). It is a case where freedom of expression was brought to new heights. Two teenagers had placed and burned a cross in the backyard of a black couple living in a white neighbourhood. They were convicted under a St Paul's hate crime ordinance which prohibited the placing on any property of a symbol that might arouse "anger, alarm, or resentment in others on the basis of race, colour, creed and gender" (505 US 379). The Supreme Court, however, unanimously reversed the conviction and held that the statute was a violation of the boys' freedom of expression, though it was divided on the exact nature of the violation. The majority found that the St Paul ordinance prohibited only a certain kind of hate speech and was thus an unconstitutional and an under-inclusive, content-based limitation of expression. The four concurring justices, on the other hand, argued that the ordinance was too broad because "the mere fact that expressive activity causes hurt feeling, offence or resentment does not render the expression unprotected" (505 US 414). Either way, the boys' freedom of expression had been violated and the future of hate-speech legislation in the US was put in serious doubt.

Finally, an important case where freedom of expression prevailed over anti-discrimination measures is Hurley $v$ Irish-American LGB Group of Boston (1995: 515 US 1). In 1992 the Irish-American Gay, Lesbian and Bisexual Group of Boston applied to join the St Patrick's parade. They were turned down, but a judge held that this was an unconstitutional exclusion based upon sexual orientation and allowed them to march. One year later the Massachusetts Supreme Court confirmed this stance, but in 1995 the US Supreme Court reversed it. In a rare unanimous decision, it held that the free expression of the parade's organizers had been violated because the state was "requiring petitioners to alter the expressive content of their parade" (515 US 15). "Our tradition of free speech", the Court ruled, "commands that a speaker who takes the street corner to express his views in this way should be free from interference by the State based on the content of what he says" (515 US 21-2). Participation of gay, lesbian and bisexual people in the parade was a right, the Court emphasized, but expression of their message within the St Patrick parade was not, since "disapproval of a private speaker's statement does not legitimize use of the Commonwealth's power to compel the speaker to alter the message by including one more acceptable to others" (515 US 23-4). 


\subsection{Limits to the 'Marketplace of Ideas': State Regulation of Private Expression}

As the above discussion suggests, it is difficult to overstate the importance of freedom of expression in US law. "If there is any principle of the Constitution that more imperatively calls for attachment than any other", Justice Holmes put it in US v Schwimmer (1929: 279 US 644), "it is the principle of free thought - not free thought for those who agree with us, but freedom for the thought that we hate" (279 US 655). This liberty to allow the expression of views that are not only controversial, but are even flirting with illegality, is one of the key traits of the US Constitution as well as one of the grounds that distinguishes it from other legal systems.

Important as it undoubtedly is, however, such a remarkably robust 'marketplace of ideas' is not entirely unregulated, nor could it possibly be, since any government permitting this would come close to chaos. Reputations can be ruined, people's rights can be affected and a nation's existence can, in extreme circumstances, be jeopardized by unconditional freedom, with the result that states may have a residual interest not only in following the development of the 'market of ideas' but also in intervening when certain boundaries are crossed. Yet where does the border lie? When is the regulation of free expression justified? In other words, when does freedom become abuse?

Considering free expression's almost saintly importance in US law, one would expect regulation to take place only when narrowly-defined and very important values are at stake. Yet while this is true in theory, it has not always been the case in practice. The following examples of judicial intervention are instructive not only of the constant tension between individual expression and state regulation but also, and perhaps inevitably, of judicial intricacy. If we want to know what kind of expression US law permits, we must also look at what it prohibits.

\subsubsection{Subversive Activities and 'Clear and Present Danger'}

Self-preservation is a key concern of governments as well as individuals and, in fact, one of the earliest limitations to free expression in US law occurred in the field of advocacy of illegal acts against the state. In 1919 the Supreme Court drew a distinction between protected and unprotected advocacy in Schenck $v$ United States (1919: 247 US 47), a case involving the constitutionality of the Federal Espionage Act of 1917. "The question in every case", the Supreme Court wrote, "is whether the words used are used in such circumstances and are of such a nature as to create a clear and present danger that they will bring about the substantive evils that Congress has a right to prevent. It is a question of proximity and degree" (247 US 52).

Despite its importance for First Amendment jurisprudence, the 'clear and present danger' test was broad and prone to abuse, particularly in times of war and national emergency when the Supreme Court already had (and was going to further develop) a reputation for bowing to governmental interests. Time arguably proved critics right when only a few years after Schenck, the justices gave a remarkably deferential interpretation of what constituted illegal advocacy in Gitlow v New York (1925: 268 US 652): "If the expression's natural tendency and probable effect is to bring about the substantive evil which the legislative body might prevent" (268 US 671), the Gitlow majority wrote, then such expression is not protected by the First Amendment. Congress, in other words, could choose to "suppress the threatened danger in its incipiency" (268 US 669) simply by showing the expression's "bad tendency" (268 US 671).

In the following years the Court realized the potential risk of this decision and, in Whitney $v$ California (1927: 274 US 257), corrected its posture by adhering to Justice Brandeis's statement according to which "only emergency can justify repression" (274 US 377) and by ruling that the danger had to be "clear", "imminent", and "substantial" (274 US 379). Yet confusion did not dissipate completely and the doctrine of "clear and present danger' was also used to curtail legitimate political dissent (Note 4). The matter has since been clarified by Brandenburg $v$ Ohio (1969: 395 US 444), a case that forbids only advocacy directed to "inciting or producing imminent lawless action and is likely to incite or produce such action" (395 US 447). It should nevertheless be noted that the Supreme Court still fluctuates between libertarian and deferential approaches, with the latter particularly frequent in times of national emergency, such as the aftermath of the 9/11 terrorist attacks in New York and Washington.

\subsection{2 'Low Value' Speech and 'Fighting Words'}

Another important example of limitation to free expression is provided by so-called 'low-value speech'. The idea was first introduced by Chaplinsky $v$ New Hampshire (1942: 315 US 568), a case involving public utterance of offensive words. Mr Chaplinsky publicly inveighed against a City Marshal and called him "a God damned racketeer" and "a damned fascist" (315 US 569). He was sentenced under a state law that prohibited "offensive words" (New Hampshire, 378, 2) but appealed, arguing that the law was an unconstitutional violation of his freedom of expression. The Supreme Court disagreed: after noting that "the right of free speech is not absolute at 
all times and under all circumstances" (315 US 571), the justices observed that "there are certain well-defined and narrowly limited classes of speech, the prevention and punishment of which have never been thought to raise any Constitutional problem". "These", the Court continued, "include the lewd and obscene, the profane, the libellous, and the insulting or 'fighting' words, those which by their very utterance inflict injury or tend to incite an immediate breach of the peace" (315 US 571-2). Otherwise put, because of their meagre social value these expressions simply did not deserve entry into the free market of ideas. Yet if the Court's definition of 'fighting words' was memorable, its mention of approximate ideas like 'obscenity', 'immorality' and 'profanity' was not and led critics to argue that these expressions were 'well-defined' and 'narrowly-limited' only in the justices' minds (Note 5).

\subsection{3 'Obscenity' and 'Immorality'}

When the Court attempted to define 'obscenity', it became apparent that not even the Supreme justices were in agreement on these definitions. As Justice Brennan wrote in Roth v United States (1957: 354 US 467), "obscenity is not within the area of constitutionally protected speech or press" (354 US 485) because "implicit in the history of the First Amendment is the rejection of obscenity as utterly without redeeming social importance" (354 US 484). Yet, when they tried to define the concept, the justices stumbled into major difficulties. The question to be posed, the Roth court tentatively wrote, was "whether to the average person, applying contemporary community standards, the dominant theme of the material taken as a whole appeals to prurient interest" (354 US 489). This explanation betrayed the vagueness that unavoidably accompanies attempts at defining obscenity, a vagueness that was graphically expressed by Justice Stewart in Jacobellis v. Ohio when he wrote a sentence that he later came to regret: "I know it when I see it" (1964: 378 US 184). Justice Brennan himself, after having categorically stated in Roth that obscenity was unprotected speech, ultimately had to recognise, in dissent, that 'obscenity' was impossible to define.

Yet, the majority was unconvinced and, in Miller $v$ California (1973: 413 US 15), revised the Roth test and defined 'obscenity' as those "works which, taken as a whole, appeal to the prurient interest in sex, which portray sexual conduct in a patently offensive way, and which, taken as a whole, do not have serious literary, artistic, political or scientific value" (413 US 24). Although this definition was less controversial, the Miller Court was bitterly divided because, as Justice Douglas wrote in dissent, the justices were dealing with tastes and literature rather than law. "Obscenity - which even we cannot define with precision-is a hodge-podge", he wrote. "To send men to jail for violating standards they cannot understand, construe, and apply is a monstrous thing to do in a Nation dedicated to fair trials and due process" (413 US 43-4). Other interesting cases decided in 1991 and 1992 suggest that the Supreme Court's intermittent fascination and difficulty with ideas of 'immorality' and 'social acceptability' is not confined to a bygone age but is very much a contemporary issue (Note 6).

\subsubsection{Importance of the 'Marketplace of Ideas'}

Freedom of speech has consistently been regarded as a most (if not the most) fundamental component of US law, as well as the single most significant political freedom within the American constellation of rights (Isler, 2001). The First Amendment prohibits the federal government from "abridging the freedom of speech", and since the 1920 s its tenets have been extended to include protection against state and federal actions. Moreover, the definition of 'speech' has been broadened by the judiciary to include symbolic speech consisting of those actions that express an opinion. This then incorporates both the burning of flags as a sign of protest, as well as the display of religious signs at schools and in other places, within the rubric of expressions to be protected.

Free speech is not absolute and can be limited if it is seen as sedition, libel, 'fighting words' or obscenity, all of which are narrowly defined. Yet given the importance of free speech in US law, America's 'marketplace of ideas' is built so as to protect most forms of expression, and can only be restricted for reasons of public order .

\section{The 'Marketplace of Religions' and the Importance of Religious Freedom in US Law}

Under US law, freedom of religion is a form of protected expression that benefits from the conceptual and legal safeguards mentioned above. Because of a number of historical developments, however, religion and religious symbolism also possess a unique place in America's legal system, and the wording of the First Amendment leaves little doubt about this. The first freedom of the First Amendment of the US Bill of Rights states that "Congress shall make no law respecting an establishment of religion or prohibiting the free exercise thereof...", A product of the country's short but intense religious past, this passage was meant to recognise both that America's unusually diverse marketplace of religions was incompatible with the establishment of one over another, and that religious liberty was among the nation's most cherished achievements. The two aspects are connected because, as Madison observed, America's crowded bazaar of faiths is the most important guarantee of religious freedom (Haynes, 2007: 16). 
In order to deal with, and preserve, this market of religions, the Founding Fathers drafted a system which carefully balanced the civil and the religious, embodied by the Establishment Clause of the First Amendment. Yet it soon became apparent that a complete and hermetical separation was impossible to achieve because the secular and the spiritual tend to naturally overlap - especially in the eyes of religious people, for whom universal sovereignty precedes the civil one. "Before any man can be considered as a member of Civil Society", Madison admitted, "he must be considered as a subject of the Governor of the Universe" (in Grunt, 2001: 185). The difficult question that the Founding Fathers intentionally left open, and that the Supreme Court had to answer in interpreting the subtle words of the First Amendment was whether it was a sovereign government and a limited God, or whether it was the reverse.

That such a question involved very practical problems became clear from the early life of the Supreme Court and is exemplified by the following Sophoclean dilemma: when a law prescribes a behaviour that is at odds with the tenets of a specific religion, are exemptions for people practising that religion allowed? Put another way, can religious beliefs be accepted as a justification for an act that the law forbids? The Supreme Court's position has been far from linear. Torn between a reluctance to carve out religious exceptions and the acknowledgement of spirituality's central place in the US, the justices' legal pendulum has moved erratically. As a general principle, however, religious freedom is not delineated by the US legal system in the positive (i.e. in terms of what religions can do), but rather in the negative (i.e. in terms of exceptions to such a freedom). Religious freedom is thus the rule to which only two exclusions can apply, namely, generally applicable laws and the Establishment Clause. Both of these need to be considered in some detail.

\subsection{First Limit to Religious Freedom: Generally Applicable Laws}

\subsubsection{Polygamy and Conscientious Objection}

The question of 'religious immunity' was initially given a negative answer in Reynolds $v$ United States (1878: 98 US 145), an early but crucial case involving polygamy. Mr Reynolds, a Mormon, married a second wife and was thus convicted of bigamy. He appealed against the decision and argued that the anti-bigamy statute violated his religious freedom because Mormonism required him to marry more than once. The Supreme Court, however, rejected his argument and set an important precedent: a man could not excuse his unlawful practices because of his religion, as "to permit this would be to make the professed doctrines of religious belief superior to the law of the land, and in effect to permit every citizen to become a law unto himself" (98 US 166-7). The Court recognised that Mr Reynolds's beliefs were sincere but ruled that while he was free to believe in bigamy, he was not free to practise it.

While Reynolds fixed an important principle in US law, it was hardly a difficult case to decide as it involved an illegal practice that was widely abhorred. The following years offered more subtle (and successful) challenges based on religious exceptions to general laws - and conscientious objection was one of them.

The early cases were invariably answered in the negative. In United States v Schwimmer (1925: 279 US 644), for example, the Supreme Court turned down an applicant for US citizenship because she refused to promise that she would take up arms in defence of the country due to her belief that "all human beings are the children of God" (279 US 684). "If all or a large number of citizens oppose such defence", the justices concluded, "the 'good order and happiness' of the United States cannot long endure" (279 US 651), with the result that the state had an interest in fostering nationalism and in "safeguarding against admission of those who are unworthy" (279 US 649). Only a few years later the Court confirmed this stance in United States v Macintosh (1931: 283 US 605), a case where another conscientious objector declared himself willing to give allegiance to the United States but unwilling to put that allegiance ahead of God. This was not enough, the Court wrote, because "unqualified allegiance to the nation and submission and obedience to the laws of the land... are not inconsistent with the will of God" (283 US 625).

After a series of analogous arguments, the turning point came a short while later. The Supreme Court, heavily relying on religious tolerance, reversed its position (by now considered "fallacious" and even "abhorrent"), and allowed a Seventh-Day Adventist to serve in the army as a conscientious objector in Girouard v USA (1946: 238 US 64). "The struggle for religious liberty has through the centuries been an effort to accommodate the demands of the State to the conscience of the individual", the justices acknowledged. "The victory for freedom of thought recorded in our Bill of Rights recognizes that in the domain of conscience there is a moral power higher than the State" (238 US 68). Only a few years later, in United States v Seeger (1965: 380 US 163), believers in non-traditional but 'theistic' variances of monotheism were also offered the opportunity to object, and in 1970 the right was finally extended to those with "moral" and "ethical" beliefs in Gillette v USA (1971: 401 US 437). After initial resistance, therefore, an important general freedom was carved out of a religious exception. 


\subsubsection{Child Labour and Compulsory School System}

As a means of ensuring the transmission of knowledge to younger generations, education has always been crucial for religions as well as for governments. Since both claim a strong interest in the child's intellectual development - the first via the parents' right to enforce a religious upbringing, the second via the duty to ensure that an adequate education takes place - there is an obvious potential for conflict, particularly when religious practices diverge from the mainstream. This is exactly what happened in Prince v Massachusetts (1944: 321 US 158), a case involving child labour. Mrs Prince, a Jehovah's Witness, was convicted for permitting her offspring to sell religious magazines in the street, contrary to a Massachusetts statute that prohibited child labour. She maintained that this infringed her religious tenets as well as her right to bring up her child, but a divided Supreme Court upheld the statute. The State has a broad power to oversee the acts of children, the majority ruled, and parental authority may be restricted when doing so is in the interests of a child's welfare.

Given Prince's uncompromising stance in a case involving minor events, one would have expected the Supreme Court to reject claims of religious exceptions levied against the compulsory school system. Yet Wisconsin $v$ Yoder (1972: 406 US 205) carved out just such an exception. The case involved the withdrawal from school of children belonging to the Old Order Amish religion upon request of their parents, who believed that the education of children over the age of 14 was "too worldly" (Shawn, 2003: 28). "When the children get to that age", one Amishman stated, "You got to get that religion in them. Just like when you plant a tree, you got to plant it straight or it will always be crooked" (Shawn, 2003: 94). After noting that "the values of parental direction of religious upbringing and education of their children in their early and formative years have a high place in our society" (406 US 413-4), the Court ruled that the state's interest in educating children should succumb to Amish parents' religious freedom. "Long before there was general acknowledgement of the need for universal formal education, the Religion Clauses had specifically and firmly fixed the right to free exercise of religious beliefs", the Court concluded (406 US 414). The Wisconsin statute compelled Amish parents to perform acts which were at odds with a fundamental tenet of their religion, and since the state's interest was not as substantial as the parents', Wisconsin had to carve out an exception to the compulsory educational system specifically for Amish children.

\subsection{3 'Right to Discriminate' and Religious Exemptions in the Workplace}

Just how important religion is to US constitutional law was made clear by the Supreme Court in Corporation of the Presiding Bishop v Amos (1987: 483 US 327), a case involving the constitutionality of exemptions to anti-discrimination statutes. After being fired by his employer (a corporation affiliated to the Church of Jesus Christ of Latter-day Saints) because he was not a member of that congregation, a building engineer sued, claiming that he was discriminated against on religious grounds. The Supreme Court recognised that this was the case, but unanimously found that the dismissal was justified because religious organizations were exempt from religious discrimination law. "It is a permissible legislative purpose", the Court wrote, "to alleviate significant government interference with the ability of religious organizations to define and carry out their religious missions" (483 US 335). Put another way, since government had an interest in guarding against interference in religion, religious organizations could be constitutionally exempted from certain laws that apply to others.

Religious exceptions in the workplace had a more tortuous outcome. In 1963 the Supreme Court, in Sherbert v Verner (1963: 374 US 398), ruled that a member of the Adventist Church who had been fired because of her refusal to work on Saturdays (her faith's Sabbath) had a right to unemployment benefits. Deciding differently would, the Court wrote, "force her to choose between following the precepts of her religion and forfeiting benefits, on the one hand, and abandoning one of the precepts of her religion in order to accept work, on the other hand" (374 US 404). Justice Douglas wrote in a concurring opinion that this would amount to interference "as plain as it is in Soviet Russia" (374 US 412). According to the majority, states had to recognize the unique requirements of religious traditions, because "to condition the availability of benefits upon the applicant's willingness to violate a cardinal principle of her religious faith effectively penalizes the free exercise of her constitutional liberties" (374 US 406). This was not tantamount to giving special privileges to religious people, the justices concluded, but simply guaranteed equality.

Although Sherbert has long been considered the reference case for religious exceptions in the workplace, in 1990 the Supreme Court took a different path in Employment Division v Smith (1990: 494 US 872), a case where the justices held that neutral, generally applicable laws can be applied to religious practices even when they are not supported by a "compelling governmental interest" (494 US 873) as decided in Verner. Interestingly, however, the justification given was not based upon secular arguments but rather on the fact that ruling otherwise would have endangered the very existence of America's marketplace of religions: "Any society 
adopting religious exceptions to general laws would be courting anarchy", the majority wrote, "but the danger increases in direct proportion to the society's diversity of religious beliefs.... Precisely because 'we are a cosmopolitan nation made up of people of almost every conceivable religious preference', we cannot afford the luxury of deeming presumptively invalid ... every regulation of conduct that does not protect an interest of the highest order" (494 US 888). This decision was the object of much criticism in America and several states passed laws that confirmed Sherbert, circumventing the Supreme Court's strictness. Yet this controversy remains emblematic of the dilemma in balancing individual conscience and state rules.

\subsection{Second Limit to Religious Freedom: The Establishment Clause}

Although the markets of ideas and religions are intimately connected, they differ in three fundamental and problematic respects. The first is that contrary to popular opinion, religious beliefs involve practices as well as thoughts, and this is exactly why the First Amendment protects the exercise of religion as well as its belief. The second is that religion is only apparently a private matter. Concerned as they are with human conduct, religious movements take, by definition, a holistic approach to life, which is by necessity reflected in public issues as well. The third aspect of difference is a question of priority: although civil and religious authorities stand on different levels, for a religious person there is usually little doubt which one prevails in case of conflict (McConnell, 1990: 1446). Although this duality is not necessarily negative - as Lord Acton wrote, it is "to that conflict of four-hundred years that we owe the rise of civil liberty" (in McConnell, 1990: 1513) - it is a potential problem for governments, particularly in a country where religions number in the hundreds.

The Founding Fathers were deeply aware of all this and responded by creating a unique constitutional mechanism where religious freedom is balanced against the words of the Establishment Clause, which states that "Congress shall make no law respecting an establishment of religion". This provision has two important implications. First, contrary to what happens in the marketplace of ideas, in the matter of religious exceptions to generally applicable laws America's marketplace of religions is not only a source of religious freedom but also an important limit to it, because the larger the number of religious groups, the more imperative it becomes for a government to maintain neutrality. The second implication has to do with the interpretation of the religious clauses: the difficulty of finding a constitutional balance between free exercise and anti-establishment produces a situation of internal inconsistency that at times favours religion and at other times appears hostile to it. The fact that the first situation is regarded by secularists as a judicial deformation of a godless Constitution, and the second is seen by religious groups as an inaccurate interpretation of a spiritually-oriented system, is one more example of the controversial, but crucial, place occupied by religion in US law. This section briefly analyzes such complexity in the Establishment Clause jurisprudence with reference to three sensitive areas of education, namely, public contributions, curriculum and religious symbolism.

\subsubsection{Public Contributions}

The matter of public contributions to religious education provides a good example of Establishment Clause complexity and is best illustrated by Everson $v$ Board of Education (1947: 330 US 1), a case most renowned for the justices' comprehensive — indeed, all-inclusive - definition of 'establishment' (330 US 15-6):

The 'establishment of religion' clause of the First Amendment means at least this. Neither a state nor the Federal Government can set up a church. Neither can pass laws which aid one religion, aid all religions, or prefer one religion over another... No tax in any amount, large or small, can be levied to support any religious activities or institutions, whatever they may be called, or whatever form they may adopt to teach or practice religion. Neither a state nor the Federal Government can, openly or secretly, participate in the affairs of any religious organizations or groups and vice versa.

Since this passage seemingly outlawed public funds for all religious purposes whatsoever-and considering that Everson involved a law authorizing public schools to reimburse parents for the money spent on the transportation of children to religious schools - one would have expected the Supreme Court to strike down the legislation as unconstitutional. Yet this did not happen. The justices held that the statute was valid because the money was given to parents, not to schools, and thereby narrowed the broad definition of establishment that they had just spelled out.

Everson is all the more peculiar when compared with the Supreme Court's approach in the other leading case on financial contributions to religious education, Lemon v Kurtzman (1971: 403 US 602). At issue here were two statutes that financially aided teachers of secular subjects in church-related schools. Entirely distancing itself from the Everson test and outcome, the Court concluded that both pieces of legislation were unconstitutional. In order to determine whether a statute violated the Establishment Clause, the justices argued, a new three-pronged test was necessary: "First, the statute must have a secular legislative purpose. Second, its principal or primary 
effect must be one that neither advances nor inhibits religion; finally, the statute must not foster 'excessive entanglement with religion"” (403 US 612-3). The legislation at issue did not pass the third test and was thus held as unconstitutional. As for the Lemon test, it still remains the main lens through which the Supreme Court assesses Establishment Clause queries, but its broad wording has only reduced - and certainly has not dissipated - the doubts created by Everson.

\subsubsection{School Prayers, Bible Reading and Ten Commandments}

The complexity of the Supreme Court's approach on Establishment Clause issues is also visible in the matter of religious symbolism. Although the justices have been fairly consistent in their rejection of public religious symbols at school, this directly conflicts with their position on symbolism in other areas of public life.

In the leading case on the matter, the justices decided that state-enforced school prayers were unconstitutional even if voluntarily recited. "The constitutional prohibition against laws respecting an establishment of religion", the Court wrote in Engel v Vitale (1962: 370 US 421), "must at least mean that in this country it is no part of the business of government to compose official prayers for any group of the American people to recite as part of a religious programme carried on by government" (370 US 425). This position was confirmed one year later in Abington v Schempp (1963: 374 US 203), where the Court decided that official and daily school readings of Bible passages were unconstitutional because they amounted to "religious exercises required by the States in violation of the command of the First Amendment that the Government maintain strict neutrality, neither aiding nor opposing religion" (374 US 225). Although, like in Engels, the Abington Court conceded that "today, as in the beginning, our national life reflects a religious people" (274 US 213), it countered that "religious freedom is...likewise as strongly embedded in our public and private life" (274 US 214) and warned that "the breach of neutrality that is today a trickling stream may all too soon become a raging torrent" (374 US 225).

Indeed, issues related to this contentious matter continued, and in 1980 it was the turn of the Ten Commandments to fall under the scrutiny of the Supreme Court. Although a Kentucky law had required the posting of the Commandments in every public school, the Supreme Court decided that this was unconstitutional: "The Ten Commandments are undeniably a sacred text in the Jewish and Christian faiths", the justices wrote in Stone v Graham (1980: 449 US 39), "and no legislative recitation of a supposed secular purpose can blind us to that fact" (449 US 41). Being sacred, the Commandments can do nothing but encourage a religious education, and will "induce schoolchildren to read, meditate upon, perhaps venerate and obey, the Commandments", the Court wrote. "However desirable this might be as a matter of private devotion, it is not a permissible state objective under the Establishment Clause" (449 US 42).

Finally, a few years later the Supreme Court extended its jurisprudence of neutrality on public school symbolism when it decided, in Wallace $v$ Jaffree (1985: 472 US 38), that an Alabama law authorizing a period of silence in public schools for the purpose of "meditation or voluntary prayer" (472 US 40) also violated the Establishment Clause. "The addition of 'or voluntary prayer' indicates that the State intended to characterize prayer as a favored practice", the Court concluded. "Such an endorsement is not consistent with the establishment principle that the government must pursue a course of complete neutrality toward religion" (472 US 60).

\subsubsection{Public Display of Religion Outside of School}

While the Supreme Court has been consistent in opposing public religious symbolism at school, the same cannot be said for religious insignia outside the classroom. Not only have the justices explicitly recognized the constitutionality of religious holidays displays and Sunday closing laws, in Marsh $v$ Chambers (1983: 463 US 783) they found that the Nebraska practice of beginning the legislative session with a prayer given by a publicly-funded chaplain was constitutional on the grounds that "the use of prayer is embedded in the nation's history and tradition" (463 US 786) and "religion has become part of the fabric of society" (463 US 783). This hardly squares well with the justices' interpretation of religious symbolism mentioned above. Moreover, it sits rather uncomfortably with the fact that the Supreme Court itself, like Congress, regularly opens it sessions with an official prayer.

\section{Conclusion}

Religion plays a controversial but crucial role in US constitutional law, and given the position of the Founding Fathers on the matter this is hardly surprising. While they were convinced that religious feelings were vital for the well-being of individuals as well as nations, they also agreed that precisely because of this, states had no right to intrude into the private conscience of its citizens and that religion should be left out of government. "Our rulers can have authority over such natural rights only as we have submitted to them", Jefferson famously wrote. "The right of conscience we never submitted, we could not submit" (in Lipscomb \& Bergh, 1903: Vol. 12, 388). 
The basic lesson of the First Amendment, therefore, exists in the acknowledgement that the US system is remarkably liberal when it comes to guaranteeing freedom of expression and religion at the individual level, but also remarkably strict when it comes to the separation of Church and State, with the marginal exception of certain practices regarded as possessing historic and symbolic significance. The brilliance of the Founding Fathers thus lies in three key areas: in this balancing between individual conscience and the law, on the one hand, and between private religious beliefs and Church-State division, on the other; in the consensus regarding the critical, if highly controversial, place of religion in the US constitution; and in the acknowledgement that it is precisely this controversy over conscience and spirituality, over the existence of an entity that is higher and morally superior to the state - whether that entity is religious or otherwise - that characterizes the US legal system and that gives sense to its entire constellation of rights. In this perpetual debate, in the constant tension between the secular and the spiritual, lies America's freedom.

\section{References}

Gedicks, F. M. (1995). The Rhetoric of Church and State. Durham: Duke University Press.

Grunt, G. (2001). The Writings of James Madison. New York: Free Press.

Haynes, C. (2007). A Muslim in the House Advances Religious Freedom. Washington: First Amendment Center.

Irons, P. (1997). May It Please the Court: The First Amendment. New York: New Press.

Isler, C., \& Fontanetta, K. (2001). The Right to Free Speech. New York: Rosen.

Lambert, F. (2002). The Founding Fathers and the Place of Religion in America. Princeton: Princeton UP.

Lipscomb, A., \& Bergh, A. (1903). The Writings of Thomas Jefferson. Washington: Library of Congress.

McConnell, M. W. (1990). The Origins and Historical Understanding of Free Exercise of Religion. Harvard Law Review, 103, 1409. http://dx.doi.org/10.2307/1341281

Shawn, F. P. (2003). The Yoder Case: Religious Freedom, Education and Parental Rights. Kansas: Kansas UP.

\section{Cases \& Statutes}

Abrams v United States (1919) 250 US 616.

Board of Education v Pico (1982) 457 US 853.

Brandenburg v Ohio (1969) 395 US 444.

Chaplinsky v New Hampshire (1942) 315 US 568.

Cohen v California (1971) 403 US 15.

Corporation of the Presiding Bishop v Amos (1987) 483 US 327.

Employment Division v Smith (1990) 494 US 872.

Engel v Vitale (1962) 370 US 421.

Everson v Board of Education (1947) 330 US 1.

Flag Protection Act (1990) 18 USC Sec. 700.

Gillette v USA (1971) 401 US 437.

Girouard v USA (1946) 238 US 64.

Gitlow v New York (1925) 268 US 652.

Hurley v Irish-American GLB Group of Boston (1995) 515 US 1.

Jacobellis v. Ohio (1964) 378 US 184.

Lemon v Kurtzman (1971) 403 US 602.

Marsh v Chambers (1983) 463 US 783.

Miller v California (1973) 413 US 15.

New Hampshire Pub. Laws (1942) ch. 378 § 2.

Prince v Massachusetts (1944) 321 US 158.

RAV v City of St.Paul (1992) 505 US 377.

Reynolds v United States (1878) 98 US 145. 
Roth v United States (1957) 354 US 467.

Schenck v United States (1919) 247 US 47.

Sherbert v Verner (1963) 374 US 398.

Stone v Graham (1980) 449 US 39.

Texas Penal Code Ann. (1989) § 42.09 (a) (3).

Tinker v Des Moines School District (1969) 393 US 503.

United States v Macintosh (1931) 283 US 605.

United States v Schwimmer (1925) 279 US 644.

United States v Seeger (1965) 380 US 163.

United States v. Eichman (1990) 496 US 310.

US v Schwimmer (1929) 279 US 644.

Wallace v Jaffree (1985) 472 US 38.

West Virginia Board of Education v Barnette (1943) 319 US 624.

Whitney v California (1927) 274 US 257.

Wisconsin v Yoder (1972) 406 US 205.

\section{Notes}

Note 1. The 'marketplace' idea was first spelled out in the dissenting opinion of Justice Holmes, Jr. (joined by Justice Louis Brandeis) in Abrams v. United States, 250 U.S. 616 (1919) and was then confirmed in several other cases. "Persecution for the expression of opinions seems to me perfectly logical", Justice Brandeis wrote. "If you have no doubt of your premises or your power and want a certain result with all your heart you naturally express your wishes in law and sweep away all opposition...But when men have realized that time has upset many fighting faiths, they may come to believe even more than they believe the very foundations of their own conduct that the ultimate good desired is better reached by free trade in ideas - that the best test of truth is the power of the thought to get itself accepted in the competition of the market, and that truth is the only ground upon which their wishes safely can be carried out. That at any rate is the theory of our Constitution". This article is a revised version of my Veiled Threats? Islam, Headscarves and Religious Freedom in America and France (2008).

Note 2. Tinker was later limited by Hazelwood v Kuhlmeier and Bethel School District v Fraser-as well as more recently by Morse v Frederick, 127 S Ct 2618 (2007), holding that schools can punish the advocacy of illegal drugs, however ineffectual the advocacy. Yet Tinker has been strongly reaffirmed when it comes to political speech and the Court has forcefully protected religious speech.

Note 3. "The way to preserve the flag's special role", the court wrote in a sentence that graphically expressed the primacy of the free marketplace model, "is not to punish those who feel differently about these matters. It is to persuade them that they are wrong... . We do not consecrate the flag by punishing its desecration, for in doing so we dilute the freedom that this cherished emblem represents" (491 US 420).

Note 4. The most notable example was the McCarthy era, when the Supreme Court justified limitations to freedom of expression of Communist Party members by arguing that given the "inflammable nature of world conditions" (341 US 498, 511) a "highly organized conspiracy with rigidly disciplined members" (351 US 587) justified state intervention.

Note 5. Although 'fighting words' is an exception that has not been extended much beyond Chaplinsky.

Note 6. In Barnes v Glen Theater (501 US 560, 1991) two women working in a strip-tease club claimed that an Indiana law prohibiting nude dancing among consensual adults violated their First Amendment right to express an erotic message. A divided Supreme Court, however, ruled that "public indecency statutes...reflect moral disapproval of people appearing in the nude among strangers in public places" (501 US 560, 568). "Our society prohibits", Justice Scalia wrote, "and all human societies have prohibited, certain activities not because they harm others but because they are considered, in the traditional phrase, contra bonos mores, ie, immoral. In American society, such prohibitions have included, for example, sadomasochism, cockfighting, bestiality, suicide, drug use, prostitution and sodomy" (Id. 575). According to the Court, 'immorality' is thus enough to justify a limitation to freedom of expression. What that term meant, however, the justices declined to say. 